\title{
The Dynamic Effects of Innovation, FDI, \& Trade Liberalization on Services Sector: An Evidence from Developed and Develop- ing Economies
}

\author{
Muhammad Zubair Chishti*1 \& Dr. Farrukh Mehmood ${ }^{2}$ \\ ${ }^{1}$ Zhengzhou University, Henan, People's Republic of China \\ ${ }^{2}$ Pakistan Institute of Development Economics, Islamabad, Pakistan
}

\begin{abstract}
The current study is a bid to explore the dynamic effects of Innovation, FDI, and trade openness on services sector in selected developed and developing economies for the period of 1992 to 2016. For computing the empirical findings, this study deploys the static as we all dynamic panel data estimation approaches. The results reveal the significant role of GDP per capita and FDI in the growth of services sector. However, the services sector incurs the detrimental repercussions on the account of trade liberalization. These findings also demonstrate that, in both samples of economies, the services sector does not respond to the productivity differential. Furthermore, innovation exhibits a significant association with the growth of services sector in the case of developing economies.
\end{abstract}

Key words: FDI, Trade Liberalization, Innovation, Developed and Developing Economies, Services Sector, Panel Data Analysis.

\section{Introduction}

A services sector plays a vital role in the development process of an economy. The economy is considered as services based-economy if it has relatively higher services share in total consumption, production and employment as compared to manufacturing and agriculture sectors. The services sector affects the economic growth directly through its increasing contribution to the output, employment and trade and indirectly through productivity growth and creating linkages with other parts of the economy (Baumol, 1967; Clark, 1940; Fisher, 1935). In servicesbased economies, services are not used only as final product but also as an intermediate input that is used to link different economic activities and make the economy function smoothly (Berlingieri et al., 2014). The growing importance of services sector and its impact on different parts of the economy has made this sector as the primary source of growth and job creation even in developing countries (Ghani and O'Connell, 2014). The most frequent use of services as an intermediate input in other parts of the economy have enhanced the overall productivity and efficiency of the economy as it is witnessed from OECD countries. Similarly, a slowdown of

*Corresponding author.

Email: chishtimz9@gmail.com

http:/ /www.jbrc.pk 
services sector productivity has brought down the overall productivity of these economies from $4 \%$ to $2 \%$ over the period 1995-2015 (Jones and Yoon, 2008). The importance of services sector in global perspective is apparent from its rising contribution in output, employment and trade. Services sector constitutes $68 \%$ of total world output, $39 \%$ of total world employment and $20 \%$ of world total trade. The services sector is characterized as the fastest growing sector not only in world economy as a whole but also in different economic groups separately. Services share in total GDP is $47 \%$ in low-income countries, $53 \%$ in middle-income countries and more than 70 per cent in high-income countries (WDI Report, 2014). The services exports reached to $\$ 4.7$ trillion with the fastest growth rate of 7 percent compared to 2 percent growth rate of the merchandise exports by 2014 which has provided great support to the world trade (WTO Statistics, 2014). This sector has also proved attractive for foreign direct investment as it has received $\$ 1.3$ trillion by the year 2014 (UNCTAD 2014).

Over the last decade, the increasing share of the services sector in GDP and employment and GDP has grabbed the attention of economists around the world. Different studies have addressed the subject issue from different angles. For example many of the studies have addressed the subject matter in the context of a single indicator as a major variable of interest, i.e. some studies investigate either the impact of per capita GDP on services sector growth (Ajmair and Ahmed, 2011; Estrada et al., 2013; Nayyar, 2009; Salam et al., 2018), some investigate the impact of FDI on services sector growth (Agya and Wunuji, 2014; Chakraborty et al., 2006; Iram and Nishat, 2009; Sen, 2011); whereas, some studies examine the impact of either GDP, productivity, trade openness or innovation on services sector growth (Mitra et al., 2013; Ramaswamy and Rowthorn, 1993; Sapprasert, 2006; Singh and Kaur, 2014; Vamvakidis and Dodzin, 1999). Most of the aforementioned studies are related to advanced countries. There are few cross country studies that look into factors affecting the services sector growth such as $\mathrm{Wu}$ (2007) focuses on China and India, while D'agostino et al. (2006) use a panel of EU countries for investigating the determinants of services sectors growth. However, according to the Russo et al. (2001) as well as Schettkat and Yocarini (2003), thanks to the diverse nature of economic development of both developed and developing countries, the role of factors affecting the services sector growth may not be the same, rather it may affect the services sector growth in both of the countries differently.

The current study contributes to accessible literature in different ways; first, unlike many previous studies that used a single indicator as a variable of interest, this study intends to investigate the impact of many factors that affect the services sector. Secondly, in the light of the studies of Russo et al. (2001) and Schettkat and Yocarini (2003), which predict different impacts of these indicators on developed and developing economies, we present a comparative picture of factors affecting the services sector growth that will help us identify factors, which are important both for developed and developing economies together and those which are important for developing or developed economies only.

\section{Theoretical Underpinnings}

Fisher (1935) and Clark (1940) were the pioneers who developed a theoretical base for the determinants of change in the whole structure of an economy. They were of the views that in the first phase of economic development, the sectoral share of agriculture in total output and employment fall, while the sectoral share of industry rises. In the second phase with further growth of an economy, the sectoral share of industry in total output and employment falls, while 
the sectoral share of services begins to rise. According to Fisher (1935), the sectoral structural transformation of an economy is due to some of the characteristics of services. It includes the relatively high-income elasticity of services as compared to goods and the persistent use of services which are used not only as primary inputs but also as secondary inputs. Due to relatively higher income elasticity and more need-satisfying nature of services as compared to goods, when income of the people increases they will prefer to purchase more services as compared to goods. Similarly, services being used as an intermediate input connect different economic activities and complete the production process. The other sectors, therefore, highly depend on services sector for their growth and development (Chenery et al., 1975). Baumol (1967) suggests that an increase in income is not the only factor behind the services sector growth, in fact the per-worker productivity difference between manufacturing sector and the services sector is also one of the main reasons. The lower per worker productivity in services sector makes this sector to employ more labour which increases services output in nominal terms rather than in real terms. Besides the factors suggested by Fisher (1935), Clark (1940) and Baumol (1967), there are some other factors that can affect the services sector growth. These other factors are outsourcing of services activities by the manufacturing firms, demographic factors and the social and economic reforms. According to Schettkat and Yocarini (2003), as an economy adopts more specialized pattern of production, each subtask of production is done with specialized firms. Since most of manufacturing firms outsource their services activities to be done with specialised services firms it results in increasing demand for services. The demographic factors like population growth, rural-urban migration and female participation in labour force increase both demand and supply of services Sabolo (1975). The social and economic reforms such as good governance, trade openness and innovation, particularly in developing economies are also considered as the main forces behind growth in the services sector Mehta (1985).

\section{Empirical Evidence}

Different empirical studies have suggested different factors as determinants of growth in the services sector. Income per capita, Productivity difference, Innovations, FDI and trade openness are the most common factors suggested by different empirical studies as determinants of services sector growth. We present here a brief empirical literature, on each of them. Fisher (1935) and Clark (1940) established the hypotheses that highlight the factors responsible for services sector growth. The contribution of these two great researchers has given the name of ClarkFisher theory or Clark-Fisher hypothesis. According to this theory, income per capita is the key determinant for the rising share of services in total output and employment. This hypothesis has empirically tested by number of empirical researchers. The empirical study of Schettkat and Yocarini (2003) suggests that income per capita is the main factor that affects services sector growth. As income per capita increases, the consumers final demand tends to shifts from goods to services. The countries with relatively higher per capita income have experienced higher share of services in output and employment. The same results have also been confirmed by Ajmair and Ahmed (2011); Estrada et al. (2013); Nayyar (2009); Salam et al. (2018). Summers (1985) suggests that though income per capita has significantly positive effect on services sector growth but this is a nominal income effect rather than real income effect. Renuka and Kalirajan (2002) empirically examined that how much higher the income elasticity of services is. They found that in fact services have positive income elasticity but it is not that much higher as was suggested by the previous empirical studies. 
The hypothesis about the lower per worker productivity in services sector presented by Baumol (1967) has also empirically tested by number of researchers. Ramaswamy and Rowthorn (1993) found that services sector is less productive as compared to manufacturing sector. Hence, there occurs a productivity gap between these two sectors. To cover the productivity gap, the services sector hires additional labour with higher wages. This increase in wages is reflected in the price of final services that causes services value added to grow in nominal terms rather than in real terms. Similar results were also confirmed by Kim (2006). However, Mitra et al. (2013) suggest that these are only a few sub sectors that are less productive while the services sector as a whole is not so much lagged behind manufacturing sector with respect to per worker productivity. Similar results were suggested by Lages and Fernandes (2005); Maroto-Sánchez (2012); Triplett and Bosworth (2003). Furthermore, Berman et al. (1994); Griliches (1992) suggest that due to conceptual problems related to the definition and measurement of per worker productivity, the services sector has mistakenly considered less productive. But now as most of the measurement errors related to the definition and measurement of productivity have been solved so the services sector is no longer seems to be less productive.

IQBAL et al. (nd) suggests that innovations have not only a positive effect on output and employment but it also have a significantly positive effect on labour productivity in both services sector and manufacturing sector. Sapprasert (2006) found that if the technological and non-technological innovations are collectively employed to the services firm, it will have a significant role in the enhancement of services firms performance. Licht et al. (1999) suggest that the innovative firms perform better than non- innovative firms. Innovations play an important role for both demand side as well as supply side of services. On one hand, it improves the quality of services while on other hand it introduces new modes of services provision.

Different studies have empirically intended to assess the effect of FDI on services sector growth and their results are different as well. Agya and Wunuji (2014) found a two way causality between FDI inflow and services sector growth. They found that FDI plays a supportive role for the development of services sector by providing financial as well as technical assistance but once the services sector grows it also enhances FDI inflow from abroad. They suggest that FDI inflow in services sector will increase services productivity. Similarly, when services sector becomes more productive, it will be able to attract more FDI from abroad. Iram and Nishat (2009) also found a significantly positive effect of FDI on services sector growth. However, Chakraborty et al. (2006) suggest that though foreign direct investment inflow obviously have positive effect on services sector growth but the effect is not significant. Furthermore, some of the empirical studies like Sen (2011) suggests a one way causation from services sector growth towards FDI rather than from FDI towards services sector growth. FDI may have either positive or negative effect on services sector growth, it depends on the direction of the flow of FDI towards different sectors. Hijzen et al. (2008) suggests that when the major share of FDI is directed towards services sector, it has a significant positive effect on services sector growth. But when major share of FDI is directed towards manufacturing sector, it shows the adverse effect on services sector growth.

There are several studies that have pointed out the positive effect of trade openness for services sector growth. Singh and Kaur (2014) suggest a significantly positive effect of trade openness on services sector growth. They suggest that in case of more free trade, the services share in total trade increases. However, the findings of Vamvakidis and Dodzin (1999) are different, they suggest that an attempts for the more open trade by reducing some of the trade barriers mostly increases trade in goods rather than trade in services. The positive or negative effect of trade openness for services sector growth depends on the income level of the trading partner. 
El Khoury and Savvides (2006) found that if the trading partner is a country with higher level of per capita income then in case of freer trade services share in total trade will rise but when the trading partner is a country with lower level of per capita income they will increase commodity share in total trade by reducing services share in total trade.

\section{Empirical Model}

The current study follows the empirical model developed by Inman (1988) with some modifications.

$$
S E R=\beta_{1} G D P P+\beta_{2} P D I F+\beta_{3} z
$$

Where SER represents services value added growth which is determined by GDP per capita annual growth (GDPP), per worker productivity difference between manufacturing sector and services sectors (PDIF) and sum of the exogenous demand shocks (z). we insert in equation(1), the other possible independent variables such as Innovation, FDI net inflow, and trade openness, through vector of exogenous demand shocks ( $\mathrm{z}$ ) and check that whether these factors significantly determine growth in services sector or not.

$$
S E R=\beta_{0}+\beta_{1} G D P P_{i t}+\beta_{2} P D I F_{i t}+\beta_{3} I N N_{i t}+\beta_{4} F D I_{i t}+\beta_{5} T O P_{i t}+e_{i t}
$$

Equation (1.1) represents a panel data model for the determinants of services sector growth in a sample of selected countries. Where $i$ in the subscript represents ith cross sections and $t$ in the subscript represents tth time periods. The current study also includes an additional terms through which the explanatory variables affect the services sector growth in interaction with these factors.

$$
\begin{array}{r}
S E R=\beta_{0}+\beta_{1} G D P P_{i t}+\beta_{2} P D I F_{i t}+\beta_{3} I N N_{i t}+\beta_{4} F D I_{i t}+\beta_{5} T O P_{i t}+C_{1} P D I F * G D P P+ \\
C_{2} I N N * F D I+C_{3} F D I * H C+C_{4} T O P * G D P P+e_{i t}
\end{array}
$$

Equation (1.2) includes the additional terms, i.e. PDIF*GDPP shows the effect of productivity difference on services sector growth in interaction with GDP per capita growth. INN*FDI is the effect of innovations on services sector growth in interaction with FDI inflow. FDI*HC is the effect of FDI inflow on services sector growth in interaction with Human Capital. Finally, TOP*GDP is the effect of trade openness on services sector growth in interaction with GDP per capita.

\subsection{The selection of Sample and the Time Period}

The current study uses a panel data set for a sample of 14 countries. The sample is further divided in to two groups, where a sample of seven developed countries (France, Germany, Italy, Japan, UK, US and Russia) belongs to a group of industrialised eight countries (G8) and the other sample of seven developing countries (Bangladesh, Egypt, Indonesia, Iran, Malaysia, Pakistan and Turkey) belongs to a group of developing eight countries (D8). The data period 1992-2016 covers 25 years and the data source is World Bank database (2016). The selection of these two specific samples of countries is based on the fact that they have an economic and social interaction which is necessary element in determining the factors effecting services sector 
growth in these countries. Furthermore, the selection of seven countries from each group is due to the data availability on different variables for these countries. One country from each group (Canada and Nigeria from developed and developing countries respectively) has been dropped due to lack of data availability on different variables for these two countries. Similarly, the selection of data over 1992-2016 is, because only for this specific period the data is available for all the variables included in the model.

\subsection{Variables Construction}

The current study estimates two equations, i.e. equation (1.1) and equation (1.2). the equation (1.1) uses services value added annual growth as a dependent variable, while GDP per capita growth, productivity difference between manufacturing and services sector, innovations, FDI and trade openness as an explanatory variables. The equation (1.2) is a different variant of equation (1.1), it also uses services value added annual growth as a dependent variable; while beside the explanatory variables mentioned above this equation uses some additional explanatory variables that is $\mathrm{PDIF}^{*} \mathrm{GDPP}, \mathrm{INN}{ }^{*} \mathrm{FDI}, \mathrm{FDI}^{*} \mathrm{HC}$ and TOP*GDPP.

Most of the variables like services value added annual growth, GDP per capita growth, innovations, foreign direct investment and trade openness have directly taken from World Bank Database (2016) while Productivity difference between manufacturing sector and services sector have been constructed by subtracting per worker productivity in services sector from per worker productivity in manufacturing sector. Furthermore the additional explanatory variables included in equation (1.2) i.e., $\mathrm{PDIF}^{*} \mathrm{GDPP}$, INN*FDI, FDI ${ }^{*} \mathrm{HC}$ and TOP*GDPP have been constructed by multiplying each of the two terms. For example the variable PDIF*GDPP is obtained by the multiplication of Productivity difference between manufacturing sector and services sector and GDP per capita annual growth rate, and so on see table 1 in appendix.

\subsection{Estimation Procedure}

The estimation procedure includes the use of both the static panel data estimation technique as well as the dynamic panel estimation technique. The Static Panel Data estimation technique includes Pooled OLS model, Random Effect model and Fixed Effect model while dynamic panel data estimation technique here includes only Difference GMM. The Pooled OLS model is based on the assumption that there is neither any significant cross section effect nor any significant temporal effect indicating that all intercept coefficients are same. The random effect model keeps a common intercept for all the cross sections and follows the assumption of the random unobserved individual component. However; the fixed effect model allows intercept for each cross section to be significantly different.

\subsection{Endogeneity Issue and its Solution}

The economic theory suggests a reverse causality from services sector growth towards FDI and GDP per capita as well. In case of endogeneity issue, the use of static panel data estimation techniques will lead us towards biased estimation. The appropriate choice here is the use of instrumental variable technique that is Difference GMM estimator. The difference GMM estimation technique presented by Arellano and Bond (1991) treats the issue of endogeneity as well as heteroscedasticity. It eliminates the time invariant country specific effect by taking first difference of the level equation and then using this first difference of the level equation as an 
instrument. The use of first difference of level equation as an instrument is considered weak instruments. Blundell and Bond (1998) therefore, provided System GMM an extended version of Difference GMM that once take level equation as an instruments for lag equation and then taking lag equation as an instruments for level equation also. But this is beyond the scope of this study and if the instruments are valid then difference GMM is better option and no need to further move for System GMM. The instruments are considered to be valid if it having correlation with endogenous variables $\operatorname{Cov}(, \mathrm{x}) 0$ but no correlation with error term $\operatorname{Cov}(, \mathrm{u})=0$. The selection of valid instruments is necessary to obtained more consistent and efficient estimation with Instrumental variable technique (GMM).

\section{Estimation Results}

Table (2) contains the results obtained for the combined sample of selected developed and developing countries. The current study begins to estimate equation (1.1) with static panel data estimation techniques that is Pooled OLS model, Random Effect model and Fixed effect model. We have used Brush pagan Lagrangian Multiplier test to choose between Pooled OLS and Random effect model. While the selection between Random effect model and fixed effect model is based on Hausman model specification test. The Breusch-Pagan LM test failed to reject the null hypothesis of no random effects for the combined sample of selected developed and developing countries and suggest pooling the data and estimating the model with Pooled OLS estimation technique. The Hausman specification test could not reject the null hypothesis and prefers fixed effect model over random effect model. Although, results obtained with Pooled OLS, Random effect and fixed effect models are almost according to the theory but still the model needs to be estimated with Dynamic panel data estimation technique that is Difference GMM which can better treat the issue of endogeneity and provide more accurate results. When we estimate equation 1.1, for the combined sample of selected developed and developing countries with Difference GMM; so, out of five explanatory variables only the two variables that is GDP per capita and innovations have appeared with significant coefficients at $1 \%$ and $10 \%$ respectively. The positive sign of these two coefficients indicate that each of them have increasing effect on services sector growth.

Although, the other factors like Productivity difference, FDI net inflow and trade openness also matter for the growth of services sector but currently each of them could not show a significant effect. The insignificant effect of these variables may be due to the reason as we have combined the data of two different samples that are developed countries and developing countries so they may suffer from aggregation bias. To know the real nature of the effect of these factors on services sector growth, it is necessary to analyse the whole sample into two separate groups, i.e. sample of chosen developed and selected developing economies.

Table 3 and table 4 shows the results obtained for chosen developed and selected developing economies respectively. For each of the two samples we estimate regression for equation (1.1) with Difference GMM estimator. The results show certain improvement for each of the two samples. In case of developed countries, out of five explanatory variables, the three variables (GDP per capita, FDI and trade openness) show significant effect. Besides, in chosen developing economies, four out of five variables (GDP per capita, FDI, innovations and trade openness) demonstrate the association with services sector growth significantly.

The coefficient of GDP per capita has appeared significant with positive sign in case of both samples of selected developed and selected developing countries. It indicates that services in 
Table 5.1: Results for a combined sample of developed and developing economies

\begin{tabular}{lcccc}
\hline Independent Variables & \multicolumn{3}{c}{ Static Estimation } & Dynamic Estimation \\
& Pooled OLS & RE & FE & Diff- GMM \\
\hline SERt-1 & & & & -0.06448 \\
\hline GDPP & 0.5925098 & 0.5271118 & 0.4571263 & -0.23 \\
\hline PDIF & $(0.000)^{* * *}$ & $(0.000)^{* * *}$ & $(0.000)^{* * *}$ & $(0.000)^{* * *}$ \\
\hline INN & 2.18 & 8.57 & 2 & -5.95 \\
\hline FDI & -0.96 & -0.985 & -0.651 & -0.425 \\
\hline TOP & -2.3 & -3.64 & -3.89 & 0.0000268 \\
\hline P- value & -0.106 & -0.082 & -0.383 & $(0.056)^{*}$ \\
\hline Instruments & -0.0451025 & 0.0364163 & 0.0932442 & -0.1229849 \\
\hline AR2 test & -0.672 & -0.735 & -0.385 & -0.602 \\
\hline Observations & 1.471964 & 0.3989544 & -6.108935 & -3.461909 \\
\hline B-P LM test & $(0.005)^{* * *}$ & -0.588 & $(0.000)^{* * *}$ & -0.641 \\
\hline Haulue & 336 & 336 & 336 & 308 \\
\hline
\end{tabular}

these countries are considered more luxuries and more need satisfying as compared to goods, hence, when income per capita increases in these countries, the public tends to further increase their demand for services as compared to goods. The coefficient magnitude of GDP per capita in a sample of selected developing countries (0.76) is greater than the coefficients magnitude of GDP per capita in selected developed countries (0.60). It indicates that the income elasticity of services is higher in selected developing countries as compared to the selected developed countries. These results are in accordance withEstrada.et.al,(2013)that reporta significant positive association between GDP per capita and services sector growth. 
Table 5.2: Results for selected developed economies

\begin{tabular}{|c|c|c|c|c|}
\hline \multirow{2}{*}{ Independent Variables } & \multicolumn{3}{|c|}{ Static Estimation } & \multirow{2}{*}{$\begin{array}{c}\text { Dynamic Estimation } \\
\text { Diff- GMM }\end{array}$} \\
\hline & Pooled OLS & RE & FE & \\
\hline \multirow[t]{2}{*}{ SERt-1 } & & & & 0.0062811 \\
\hline & & & & -0.949 \\
\hline \multirow[t]{2}{*}{ GDPP } & 0.7708793 & 0.7708793 & 0.7677959 & 0.60684 \\
\hline & $(0.000)^{* * *}$ & $(0.000)^{* * *}$ & $(0.000)^{* * *}$ & $(0.000)^{* * *}$ \\
\hline \multirow[t]{2}{*}{ PDIF } & -0.0006287 & -0.0006287 & -0.0014522 & 0.007428 \\
\hline & -0.402 & -0.401 & -0.527 & -0.28 \\
\hline \multirow[t]{2}{*}{ INN } & 0.0210341 & 0.0210341 & 0.2747879 & 0.4745105 \\
\hline & -0.859 & -0.859 & -0.476 & -0.512 \\
\hline \multirow[t]{2}{*}{ FDI } & 0.2428669 & 0.2428669 & 0.1388773 & 0.2619307 \\
\hline & $(0.002)^{* * *}$ & $(0.002)^{* * *}$ & -0.128 & $(0.037)^{* *}$ \\
\hline \multirow[t]{2}{*}{ TOP } & -3.24761 & -3.24761 & -4.163366 & -9.476171 \\
\hline & $(0.001)^{* * *}$ & $(0.001)^{* * *}$ & $(0.028)^{* *}$ & $(0.000)^{* * *}$ \\
\hline Observations & 175 & 175 & 175 & 161 \\
\hline $\mathbf{R 2}$ & 0.691 & 0.691 & 0.6643 & \\
\hline B-P LM test & 0 & & & \\
\hline p-value & -1 & & & \\
\hline Hausman test & & 5.63 & & \\
\hline P-value & & -0.344 & & \\
\hline Instruments & & & & 27 \\
\hline AR2 test & & & & 1.21 \\
\hline p-value & & & & -0.226 \\
\hline Sargan test & & & & 66.56 \\
\hline p-value & & & & -0.13 \\
\hline
\end{tabular}

Productivity difference between manufacturing sector and services sectors could no more show a significant effect on services sector growth in both chosen developed and selected developing economies. The insignificant effect of productivity difference suggests that the services sector has never been less productive as compared to manufacturing sector. In fact there were some errors related to the definition and measurement of services sector productivity, which has shown the services sector lesser productive as compared to manufacturing sector (MarotoSánchez, 2012). Although, there are few categories of services that are lagged behind in productivity as compared to manufacturing sector but services sector as a whole does not have the 
Table 5.3: Results for selected Developing economies

\begin{tabular}{|c|c|c|c|c|}
\hline \multirow[t]{2}{*}{ Independent Variables } & \multicolumn{3}{|c|}{ Static Estimation } & \multirow{2}{*}{$\begin{array}{c}\text { Dynamic Estimation } \\
\text { Diff- GMM }\end{array}$} \\
\hline & Pooled OLS & RE & FE & \\
\hline \multirow[t]{2}{*}{ SERt-1 } & & & & -0.1221 \\
\hline & & & & -0.144 \\
\hline \multirow[t]{2}{*}{ GDPP } & 0.8109663 & 0.8109663 & 0.7694365 & 0.76875 \\
\hline & $(0.000)^{* * *}$ & $(0.000)^{* * *}$ & $(0.000)^{* * *}$ & $(0.000)^{* * *}$ \\
\hline \multirow[t]{2}{*}{ PDIF } & 0.0000855 & 0.0000855 & 0.0000963 & 0.0002094 \\
\hline & -0.796 & -0.796 & -0.762 & -0.554 \\
\hline \multirow[t]{2}{*}{ INN } & 0.5650983 & 0.5650983 & 1.107889 & 0.8672283 \\
\hline & $(0.004)^{* * *}$ & $(0.003)^{* * *}$ & $(0.000)^{* * *}$ & $(0.081)^{*}$ \\
\hline \multirow[t]{2}{*}{ FDI } & 0.2032876 & 0.2032876 & 0.2000556 & 0.3142237 \\
\hline & $(0.092)^{*}$ & $(0.090)^{*}$ & $(0.088)^{*}$ & $(0.026)^{* *}$ \\
\hline \multirow[t]{2}{*}{ TOP } & 0.238635 & 0.238635 & -7.882495 & -7.549656 \\
\hline & -0.618 & -0.617 & $(0.000)^{* * *}$ & $(0.056)^{* *}$ \\
\hline Observations & 175 & 175 & 175 & 161 \\
\hline R2 & 0.6177 & 0.619 & 0.1173 & \\
\hline B-P LM test & 0 & & & \\
\hline p-value & -1 & & & \\
\hline Hausman test & & 21.9 & & \\
\hline P-value & & $(0.0005)^{* * *}$ & & \\
\hline Instruments & & & & 47 \\
\hline AR2 test & & & & 0.9 \\
\hline p-value & & & & -0.368 \\
\hline Sargan test & & & & 51.44 \\
\hline p-value & & & & -0.127 \\
\hline
\end{tabular}

Values in the parenthesis are P-values.

$* * * * *,{ }^{*}$ represents significance at $1 \%, 5 \%$ and $10 \%$ respectively.

productivity related issues (Mitra et al., 2013). Furthermore, due to technological advancement and introduction of new modes of production, the per worker productivity in services sector has been increased and the productivity difference between manufacturing sector and services sector has been narrowed in last two decades (Triplett and Bosworth, 2003).

Although, services sector growth does not respond to innovations in case of developed countries but its effect on services sector growth is significant in case of selected developing countries. 
These results are in line with Wang (2013), which suggest that after World War II the role of innovations have increased in developing countries which have smaller size market while its role has decreased in developed countries with large size of market. The main reason behind insignificant effect of innovation on services sector growth in case of developed countries is that the development of new technology involves high expenses and uncertainties. To have more cost effective innovations, the technologically advanced countries sought innovation opportunities off-shore in developing countries (Paeth and Mannig, 2013). Hence, role of Innovations is more important in developing countries rather than in developed countries.

The coefficient of FDI for both selected developed and developing countries has appeared significant with positive sign that indicates its supportive role for services sector in both sample of selected developed and selected developing countries. FDI inflow brings modern technology that improves human capital in host country and introduces new modes of services provision. For developed economies, FDI is a source of financial inflow while for developing countries foreign direct investment is not only the source of financial inflow but also a complete package of technology transfer, skills and technical know-how. FDI inflow provides relatively greater support to the developing countries, this is obvious also from the coefficient magnitude of FDI in a sample of selected developing countries (0.31) which is greater than the coefficient magnitude of FDI in a sample of selected developed countries (0.26).The supportive role of FDI for services sector growth has also suggested by Jain and Ninan (2010).

Trade openness exhibits significant with negative impact in case of both samples of selected developed and developing countries. It indicates that as these countries experience high degree of trade openness it increases foreign demand for their goods rather than services. Hence, both of these two groups of countries need to maintain the degree of trade openness at such a threshold level that could increase trade in goods without decreasing trade in services. As the coefficient magnitude of trade openness is relatively greater in case of selected developed countries (-9.4) as compared to the coefficient magnitude in case of selected developing countries (-7.4). So it is obvious that services trade in selected developed countries is more sensitive to the degree of trade openness as compared to the selected developing countries. Our results are in accordance with Vamvakidis and Dodzin (1999).

While moving towards equation (1.2) the results slightly change with respect to signs and significance. Table 5 contains the results obtained by estimating the equation (1.2) that includes the interaction terms as well. The results obtained by estimation of equation (1.2) for combined sample of developed and developing countries show that the explanatory variables do not have any significant effect on services sector growth in interaction with other variables. The coefficient of $\mathrm{PDIF}^{*} \mathrm{GDP}, \mathrm{INN}^{*} \mathrm{FDI}, \mathrm{FDI}^{*} \mathrm{HC}$ and $\mathrm{TOP}^{*} \mathrm{GDP}$ all are insignificant. While moving towards selected developed countries and selected developing countries separately, the results show some improvement. The effect of productivity difference in interaction with GDP per capita growth (PDIF*GDPP) possesses no significant association with services sector growth in a sample of selected developed countries and also in sample of selected developing countries. The effect of innovation on services sector growth in interaction with FDI has found significant positive in case of both samples of selected economies. It indicates that when services sector become more innovative it can easily attract foreign direct investment from abroad. The effect of FDI in interaction with Human Capital has found significant positive in case of both selected developed and selected developing countries. The positive effect of FDI in interaction with human capital suggest that as innovations increases it improve the human capital by providing new skills and technical know-how which causes the growth of services sector.

Although, the effect of innovations without interaction term was insignificant for services 
Table 5.4: Results for interaction

\begin{tabular}{|c|c|c|c|}
\hline \multirow[t]{2}{*}{ Independent Variables } & \multicolumn{3}{|c|}{ Estimation results based on GMM } \\
\hline & Combined & Developed & Developing \\
\hline \multirow[t]{2}{*}{ SERt-1 } & -0.0439 & 0.2289874 & -0.02208 \\
\hline & -0.452 & -0.104 & -0.678 \\
\hline \multirow[t]{2}{*}{ GDPP } & -0.55742 & -0.38408 & 0.57037 \\
\hline & -0.376 & $(0.075)^{*}$ & $(0.000)^{* * *}$ \\
\hline \multirow[t]{2}{*}{ PDIF } & 0.00014 & 0.00059 & 9.02 \\
\hline & -0.429 & -0.932 & -0.647 \\
\hline \multirow{2}{*}{ INN } & 2.08847 & -3.15227 & 1.65546 \\
\hline & $(0.045)^{* *}$ & -0.134 & $0.099^{*}$ \\
\hline \multirow[t]{2}{*}{ FDI } & 2.84428 & -19.06457 & 6.8949 \\
\hline & $(0.012)^{* *}$ & $(0.003)^{* * *}$ & $(0.001)^{* * *}$ \\
\hline \multirow[t]{2}{*}{ TOP } & -5.90729 & 6.484798 & -8.70583 \\
\hline & $(0.497-)$ & $\left(0.010^{* *}\right)$ & $(0.000)^{* * *}$ \\
\hline \multirow[t]{2}{*}{ PDIF*GDP } & -0.00003 & -0.00033 & -2.03 \\
\hline & -0.369 & -0.392 & -0.642 \\
\hline \multirow[t]{2}{*}{ INN*FDI } & -0.06412 & 0.73335 & 0.82739 \\
\hline & -0.778 & $(0.004)^{* * *}$ & $(0.001)^{* * *}$ \\
\hline \multirow[t]{2}{*}{ FDI*HC } & -0.02124 & 0.1115578 & -0.00248 \\
\hline & -0.293 & $(0.060)^{*}$ & -0.869 \\
\hline \multirow[t]{2}{*}{ TOP*GDPP } & 0.82844 & 0.738815 & 0.15751 \\
\hline & -0.139 & $(0.012)^{* *}$ & $(0.005)^{* * *}$ \\
\hline Observations & 308 & 154 & 155 \\
\hline Instruments & 24 & 68 & 46 \\
\hline AR2 test & -1.21 & 0.53 & -1.33 \\
\hline p-value & -0.226 & -0.59 & -0.185 \\
\hline Sargan test & 17.34 & 97.35 & 55.2 \\
\hline p-value & -0.239 & $(0.0 .001)$ & -0.021 \\
\hline
\end{tabular}

Values in the parenthesis are P-values.

${ }_{* * *},{ }^{* *},{ }^{*}$ represents significance at $1 \%, 5 \%$ and $10 \%$ respectively.

sector growth in a sample of selected developed countries but using innovation with interaction term this effect has become significant. Similarly the coefficient of trade openness in interaction 
with GDP per capita TOP*GDPP is significant positive. The sign of the coefficient has changed from negative when it was used without interaction of GDP per capita in equation (1.1) to the positive sign in the current equation (1.2). The positive sign of TOP*GDPP indicates that as the degree of trade openness increases it increases the trade in services which further has positive effect on income per capita and then on services sector growth in case of both selected developed countries and selected developing countries.

\section{Conclusion}

On the basis of empirical results, the current study concludes that GDP per capita, trade openness and FDI are the possible factors which affect the services sector growth in selected developed countries. While in case of selected developing countries these factors are GDP per capita, trade openness, FDI, and Innovations. Further, Innovations carry the significant impact on services sector growth only in case of selected developing countries while the productivity gap between manufacturing sector and services sector has no significant effect on the growth of services sector in both selected developed and developing countries. GDP Per Capita, FDI net inflow and Innovations having positive effect while trade openness has negative effect on the growth of services sector. The current study also examined the effect of these variables in interaction with other variables. Through these interactive variables, the explanatory variables affect services sector growth. In case of selected developed countries innovations in interaction with FDI, FDI in interaction with human capital and trade openness in interaction with GDP per capita have shown significant positive effect on the services sectors growth. However, in case of selected developing countries only the two variables that is Innovation in interaction with FDI and trade openness in interaction with GDP per capita have shown significant positive effect on services sector growth. Furthermore, the productivity difference in interaction with GDP per capita (PDIF*GDPP) is insignificant in both the sample of selected developed and developing countries.

When the explanatory variables are used in interaction with other variables, our results change slightly with respect to signs and significance of different variables. The innovations which was significant only in case of selected developing countries (when it was used without interaction with FDI)but now it has significant positive effect on services sector growth in interaction with FDI (INN*FDI) in both the samples of selected developed countries as well as in the sample of selected developing countries. The coefficient of FDI in interaction with human capital is insignificant in case of the sample of selected developing countries, however it was significant when it was used without interaction with human capital.

\subsection{Policy Implications}

As FDI has significant positive effect on services sector growth in both selected developed and selected developing countries. FDI inflow can enhance the process of human capital development, enhance labor efficiency by providing latest skills and technical know-how as well as it also creates new jobs. FDI is a source of financial and technology transfer to the recipient countries which have a spillover effect on growth and development of the economy as a whole. Developing countries need to focus on measures that are helpful to attract FDI from abroad, particularly, in sectors which are more knowledge intensive and require high technology and research \& development. Furthermore, our empirical results indicate that despite of relatively 
higher share of service in output and employment, the productivity of this sector is still lagging behind the manufacturing sector. The relatively lower productivity of the services sector is due to relatively less innovative activities practiced in services sector. The services sector remained deprived of innovations practices because of the traditional view that considers services sector mostly as not innovative. But the reality is not so, although the innovations in services may have some hurdles as services activities are of more heterogeneous nature where some of the services categories are not innovative but most of the services categories are knowledge intensive which can be made more productive by services innovation. The services sector can perform an important role particularly in developing countries whose structure of output and employment has been shifted from agricultural and industrial goods to the production of knowledge intensive services. The productivity of this sector can be enhanced by product innovations (introducing new goods or services), process innovations (introducing new production techniques) and marketing innovations (the implementation of new marketing strategy of goods and services). The innovations in services can be promoted through technology development and introducing new ideas of production. Hence, there is a need to give proper attention to innovations in services by designing appropriate innovation framework that focus mainly on innovations in Knowledge intensive services sectors.

\section{References}

Agya, A. A. and Wunuji, E. A. (2014). Effect of foreign direct investment on china economic growth: A granger causality approach. IOSR Journal of Economics and Finance, 2(4):56-63.

Ajmair, M. and Ahmed, U. (2011). Services sector reforms in pakistan-impacts and implications. European Journal of Scientific Research, 65(3):329341.

Baumol, W. J. (1967). Macroeconomics of unbalanced growth: the anatomy of urban crisis. The American economic review, 57(3):415-426.

Berlingieri, F., Bonin, H., and Sprietsma, M. (2014). Youth unemployment in Europe: Appraisal and policy options. ZEW Gutachten/Forschungsberichte.

Berman, E., Bound, J., and Griliches, Z. (1994). Changes in the demand for skilled labor within us manufacturing: evidence from the annual survey of manufactures. The Quarterly Journal of Economics, 109(2):367-397.

Blundell, R. and Bond, S. (1998). Initial conditions and moment restrictions in dynamic panel data models. Journal of econometrics, 87(1):115-143.

Chakraborty, C., Nunnenkamp, P., et al. (2006). Economic reforms, foreign direct investment and its economic effects in india. Technical report, Kiel Working Paper.

Chenery, H. B., Syrquin, M., and Elkington, H. (1975). Patterns of development, 1950-1970, volume 75. Oxford University Press London.

Clark, C. (1940). The conditions of economic progress, mcmillan.

D'agostino, A., Serafini, R., and WardWarmedinger, M. E. (2006). Sectoral explanations of employment in europe-the role of services.

El Khoury, A. C. and Savvides, A. (2006). Openness in services trade and economic growth. Economics Letters, 92(2):277-283.

Estrada, G. B., Acharya, Y., Batten, A., Brimble, P., Doung, P., Gulamov, M. I., Hossain, M. Z., Mellor, D. P., Park, D., and Rahman, M. S. (2013). The service sector in lower-income asian economies. Asian Development Bank Economics Working Paper Series, (347).

Fisher, A. G. (1935). The economic implications of material progress. Int'l Lab. Rev., 32:5.

Ghani, E. and O'Connell, S. D. (2014). Can service be a growth escalator in low-income countries? The World Bank. 
Griliches, Z. (1992). Introduction to" output measurement in the service sectors". In Output measurement in the service sectors, pages 1-22. University of Chicago Press.

Hijzen, A., Görg, H., and Manchin, M. (2008). Cross-border mergers and acquisitions and the role of trade costs. European Economic Review, 52(5):849-866.

Inman, R. P. (1988). Managing the service economy: prospects and problems. Cambridge University Press.

IQBAL, J., SALAM, M., and NOSHEEN, M. (n.d). The determinants of services sector growth: A cross country analysis.

Iram, S. and Nishat, M. (2009). Sector level analysis of fdi-growth nexus: A case study of pakistan. The Pakistan Development Review, pages 875-882.

Jain, S. and Ninan, T. (2010). Servicing indias gdp growth. Indias Economy Performance and Challenges, Essays in Honour of Montek Singh Ahluwalia, pages 328-65.

Jones, R. S. and Yoon, T. (2008). Enhancing the productivity of the service sector in japan.

Kim, H.-J. (2006). The shift to the service economy: Causes and effects. Institute for Monetary and Economic Research.

Lages, L. F. and Fernandes, J. C. (2005). The serpval scale: A multi-item instrument for measuring service personal values. Journal of Business Research, 58(11):1562-1572.

Licht, G., Ebling, G., Janz, N., and Niggeman, H. (1999). Innovation in the service sector. Selected Facts and Some Policy Conclusions. Paper Prepared for the Experts Group on Innovation Policy.

Maroto-Sánchez, A. (2012). Productivity in the services sector: conventional and current explanations. The Service Industries Journal, 32(5):719746.

Mehta, M. (1985). Urban informal sector: Concepts, indian evidence and policy implications. Economic and Political Weekly, pages 326-332.
Mitra, D., Ranjan, P., Eichengreen, B., and Gupta, P. (2013). Exports of services: Indian experience in perspective. Indian Growth and Development Review.

Nayyar, G. (2009). The demand for services in india. a mirror image of engel's law for food?

Paeth, H. and Mannig, B. (2013). On the added value of regional climate modeling in climate change assessment. Climate dynamics, 41(34):1057-1066.

Ramaswamy, M. R. and Rowthorn, M. B. (1993). Centralized Bargaining, Efficiency Wages, and Flexibility. International Monetary Fund.

Renuka, M. and Kalirajan, K. (2002). How incomeelastic is the consumers demand for services in singapore? International Economic Journal, 16(1):95-104.

Russo, G., Gorter, C., and Schettkat, R. (2001). Searching, hiring and labour market conditions. Labour Economics, 8(5):553-571.

Sabolo, M. Y. (1975). The service industries. International Labour Office.

Salam, M., Iqbal, J., Hussain, A., and Iqbal, H. (2018). The determinants of services sector growth: A comparative analysis of selected developed and developing economies. The Pakistan Development Review, 57(1):27-44.

Sapprasert, K. (2006). The impact of ict on the growth of the service industry. Centre for Technology, Innovation and Culture (TIK) University of Oslo.

Schettkat, R. and Yocarini, L. (2003). The shift to services: a review of the literature.

Sen, C. (2011). Fdi in the service sector-propagator of growth for india?

Singh, M. and Kaur, K. (2014). Indias services sector and its determinants: An empirical investigation. Journal of Economics and development Studies, 2(2):385-406.

Summers, L. H. (1985). Taxation and the size and composition of the capital stock: An asset price approach. Technical report, National Bureau of Economic Research. 
Triplett, J. E. and Bosworth, B. (2003). Productivity measurement issues in services industries: Baumol's disease has been cured. Economic Policy Review, 9(3).

Vamvakidis, M. A. and Dodzin, M. S. (1999). Trade and industrialization in developing agricultural economies. Number 99-145. International Monetary Fund.
Wang, C. (2013). The long-run effect of innovation on economic growth. School of Economics UNSW, Sydney, 2052.

Wu, Y. (2007). Service sector growth in china and india: A comparison. China: An International Journal, 5(1):137-154. 
Appendix A1

Table .1: Variables Included and Their Expected Signs

\begin{tabular}{|c|c|c|c|c|}
\hline & Dependent variable: & Services Valu & Added Annual Growth (SER) & \\
\hline S.no & Variables name & Notations & Construction of Variable & Expected sign \\
\hline 1 & GDP per capita & (GDPP) & $\begin{array}{l}\text { GDP / total population (an- } \\
\text { nual growth) }\end{array}$ & Positive \\
\hline 2 & $\begin{array}{l}\text { Productivity gap be- } \\
\text { tween manufacturing } \\
\text { sector and services } \\
\text { sector }\end{array}$ & (PDIF) & $\begin{array}{l}\text { (Per worker productivity in } \\
\text { Manufacturing sector) (Per } \\
\text { worker productivity in ser- } \\
\text { vices sector) }\end{array}$ & Positive \\
\hline 3 & innovations & (INN) & $\begin{array}{l}\text { Patents applications filed } \\
\text { from abroad + patents appli- } \\
\text { cations filed from inside the } \\
\text { country }\end{array}$ & Positive \\
\hline 4 & $\begin{array}{l}\text { Foreign Direct invest- } \\
\text { ment inflow }\end{array}$ & (FDI) & $\begin{array}{l}\text { Foreign Direct Investment } \\
\text { Inflow } \% \text { of GDP }\end{array}$ & Positive/Negative \\
\hline 5 & Trade Openness & (TOP) & & Positive/ Negative \\
\hline 6 & $\begin{array}{l}\text { Productivity gap be- } \\
\text { tween manufacturing } \\
\text { sector and services sec- } \\
\text { tor in interaction with } \\
\text { GDP per capita. }\end{array}$ & PDIF*GDPP & $\begin{array}{l}\text { Productivity difference be- } \\
\text { tween manufacturing sector } \\
\text { and services sector multi- } \\
\text { plied by GDP per capita an- } \\
\text { nual growth. }\end{array}$ & Positive \\
\hline 7 & $\begin{array}{l}\text { Innovations in interac- } \\
\text { tion with Foreign Direct } \\
\text { Investment }\end{array}$ & INN*FDI & $\begin{array}{l}\text { Total number of patents ap- } \\
\text { plications filed multiplied by } \\
\text { foreign direct investment net } \\
\text { inflow } \% \text { of GDP. }\end{array}$ & Positive/ Negative \\
\hline 8 & $\begin{array}{l}\text { Foreign Direct Invest- } \\
\text { ment in interaction with } \\
\text { Human Capital }\end{array}$ & FDI*HC & $\begin{array}{l}\text { Foreign direct investment } \\
\text { net inflow \% of GDP multi- } \\
\text { plied by net enrolment rate } \\
\text { secondary \% (both male and } \\
\text { female). }\end{array}$ & Positive Negative \\
\hline 9 & $\begin{array}{l}\text { Trade Openness in in- } \\
\text { teraction with GDP per } \\
\text { capita }\end{array}$ & TOP*GDPP & $\begin{array}{l}\text { trade openness multiplied } \\
\text { by GDP per capita annual } \\
\text { growth }\end{array}$ & Positive/ Negative \\
\hline
\end{tabular}

